\title{
Molecular investigation of the colicinogenic Escherichia coli strains that are capable of inhibiting E. coli O157:H7 in vitro
}

Nasrin Askari ${ }^{1}$ and Reza Ghanbarpour ${ }^{2 *}$

\begin{abstract}
Background: Escherichia coli O157:H7 is a highly virulent human pathogen with severe consequences following infection, which claims many lives worldwide. A suggested method for controlling this bacterium is the competitive elimination through using probiotic bacteria that prevent its colonization. Some nonpathogenic E. coli strains that produce antibacterial colicins are among these probiotic bacteria. We aimed to isolate and characterize the colicinogenic E. coli strains from diarrheic and healthy sheep that inhibit E. coli O157:H7, which could be used as possible probiotic sources. A total of 292 E. coli isolates (146 from each diarrheic and healthy sheep) were screened for the presence of colicin and virulence genes. The phylogenetic group/subgroup determination was performed by PCR. In vitro evaluation of inhibitory effect of colicinogenic isolates on E. coli O157:H7 was done phenotypically.

Results: The frequency of diarrhea associated colicinogenic E. coli isolates was significantly higher than those isolated from healthy sheep. An association between ETEC and the genes coding for colicin-V \& colicin-lab in diarrheic E. coli isolates was observed. Moreover, there was an association between ipaH and Colicin-V encoding genes. Furthermore, $E$. coli isolates showing bacteriocinogeny while possessing no virulence genes had a frequency of 97.67 and $11.94 \%$ in healthy and diarrheic isolates, respectively. Of these strains, five isolates (3.42\%) from diarrheic and twenty-five isolates (17.12\%) from healthy sheep inhibited O157:H7 strain. Additionally, colicin E1 and colicin lab genes were more prevalent in B1 phylogroup.
\end{abstract}

Conclusions: These results signified that healthy sheep could be considered as a potential source for anti-O175:H7 bacterial isolates.

Keywords: Escherichia coli O157; H7, Colicin, Sheep, Virulence genes, Phylogenetic groups, Probiotics

\section{Background}

E. coli O157: $\mathrm{H} 7$ is well known as a severely virulent foodborne bacterial pathogen that claims many lives annually worldwide [1]. The clinical symptoms of E. coli O157:H7 vary wildly from mild diarrhea to hemolytic uremic syndrome (HUS) leading to kidney failure. The severity of these symptoms depends on the immune status of the patient and also the infection dose of the bacteria $[2,3]$. It has been shown that the main reservoir of $E$. coli O157:H7 are ruminants [4].

However, one proposed approach for the control of $E$. coli $\mathrm{O} 157: \mathrm{H} 7$ is through the competitive elimination,

\footnotetext{
* Correspondence: ghanbar@uk.ac.ir

${ }^{2}$ Molecular Microbiology Research Group, Faculty of Veterinary Medicine,

Shahid Bahonar University of Kerman, Kerman, Iran

Full list of author information is available at the end of the article
}

which is described as the use of other probiotic bacteria to prevent the growth and colonization of the pathogenic bacterium [5]. The reduction of E. coli O157:H7 could be achieved through the use of other nonpathogenic E. coli strains that produce colicins [6]. Colicins are antimicrobial proteins synthesized by $E$. coli for inhibiting other E. coli strains as well as other closely related bacteria [7]. These proteins have evolved to provide the carrying bacterium an advantage when competing with the closely related bacteria [8]. The ability to produce colicins is common in the Enterobacteriacea family, and studies have revealed that approximately $30 \%$ of E. coli isolates are capable of producing at least one type of colicin [9].

Host animal species can effect on the type of produced colicin and bovine isolates would be expected to show 
low rate of resistance against to non-cattle Colicinogenic E. coli [5]. Zhao et al., [10] developed the first competitive- exclusion system against E. coli $\mathrm{O} 157: \mathrm{H} 7$ by isolating colicinogenic $E$. coli isolates from cattle, but little information was provided about the types of colicins produced by these isolates and the extent of resistance among naturally present $E$. coli $\mathrm{O} 157: \mathrm{H} 7$ isolates [11].

For determination of the pathogenic or non-pathogenic nature of $E$. coli isolates, assessment of the evolutionary origins via phylogenetic analysis has been helpful [12]. Based on the phylogenetic studies, E. coli isolates can be allocated to one of the four main phylogenetic groups A, B1, B2 and D, which can fall into seven subgroups [13].

Previously published studies have only provided partial insight into the association between colicin production and virulence factors, as they were mainly focused upon uropathogenic Escherichia coli (UPEC) isolates and differed in the number of detected colicin and virulence genes [14]. The present project was designed to genotypic analysis of colicinogenic $E$. coli isolates from diarrheic and healthy sheep that inhibit serotype O157:H7. Additionally, this research was set to characterized phylogenetic groups/subgroups of the isolates.

The work presented here is a continuation of our previous study. 146 of the diarrheic strains that are used in the current study were also used in a previous study where their virulence genes profiles were studied [15]. Here we aimed to further expand our investigations through analyzing these strains in terms of determination of colicin genes, phylogrouping and the inhibitory effect of them on serotype O157:H7 and comparing them with strains from healthy once.

\section{Methods}

\section{Sample collection and isolation of $E$. coli strains}

This section of the study was performed from March to Oct 2015. 167 fecal samples from healthy sheep were collected in Kerman province, Iran. Each sample was belonged to one animal which were between 1 to 12 weeks old. Swab samples were placed directly in tubes containing the Amies medium (Becton Dickinson, BBL, and USA) and sent to the laboratory for immediate processing. Samples were streaked on MacConkey agar (Merck, Germany) and incubated at $37^{\circ} \mathrm{C}$ for $24 \mathrm{~h}$. Colonies showing E. coli features were sent to Gram staining and were confirmed to be $E$. coli by using the biochemical API 20E identification system (BioMérieux, Marcy l'Etoile, France). One confirmed isolate was chosen from each plate. Finally, 146 E.coli strains from healthy sheep were stored in LuriaBertani broth (Invitrogen, Paisley, Scotland) with 30\% sterile glycerol at $-80^{\circ} \mathrm{C}$ and as the above-mentioned, 146 of the diarrheic strains that are used in the current study were also used in a previous study [15]. Therefore, the assays were done on 292 isolates (146 from each diarrheic and healthy sheep).

Ten E. coli strains were used as positive controls, including H10407 (LT-I +, ST-I+); 1404 (cdtIII +, cnf2 +, $f 17 A+) ; 510(F 5+, F 41+) ; 28 \mathrm{C}(c d t I V+, c n f 1+) ; 31 \mathrm{~A}$ $(f 17 c-A+)$; Sakaï $\left(s t x_{1}+\right.$, stx2+, eaeA+); 85b (ipaH+); 25KH9 (f17a-A+), S5 (f17b-A+); and ECOR62 (chuA +, $y j a A+$ and Tspe4 $\mathrm{C2}+$ ). The laboratory nonpathogenic E. coli MG1655 was used as a negative control. All the above-mentioned reference strains had been taken from the bacterial collection section of the Microbiology Department of Ecole Nationale Vétérinaire Toulouse, France. colicin reference strains were provided from the Pasture Institute of Iran.

\section{Molecular detection of the virulence genes and phylogenetic groups}

DNA extraction of the overnight $E$. coli cultures (current isolates and the reference isolates) was performed through the boiling method [15]. The virulence genes had been amplified and analyzed as described in details before. A complete list of the primers used for this virulence genotyping is published previously [15]. Additionally, the absence or presence of yjaA, chuA, and TSPE4.C2 sequences [13] in E. coli isolates (see Table 1), which were determined by multiplex PCR, was used to identify the phylogenetic groups.

\section{Molecular detection of the colicin genes}

All $E$. coli isolates were examined by several PCR protocols for the presence of the colicin encoding genes including colicin-Iab, V, ANS4, E1, Mix E, 5, 10, K and colicin YU [16] PCR Amplification was performed in $25 \mu \mathrm{L}$ volumes containing: $2.5 \mu \mathrm{L}$ of $10 \times$ PCR buffer, $3 \mu \mathrm{L}$ prepared DNA, $2 \mathrm{mM} \mathrm{MgCl} 2,0.3 \mathrm{M}$ of each oligonucleotide primer, $0.2 \mathrm{mM}$ dNTP mix, $1 \mathrm{U}$ Taq DNA polymerase (Cinnagen, Iran), and PCR grade water up to $25 \mu \mathrm{L}$. The PCR conditions included 1 cycle of denaturation at $94{ }^{\circ} \mathrm{C}$ for $2 \mathrm{~min}$, annealing at the Tm specific for each primer (see Table 2) for $1 \mathrm{~min}$, and elongation for $1 \mathrm{~min}$ at $72{ }^{\circ} \mathrm{C}$; subsequently 35 cycles of denaturation at $94{ }^{\circ} \mathrm{C}$ for $1 \mathrm{~min}$ and then a final $5 \mathrm{~min}$ at $72{ }^{\circ} \mathrm{C}$ hold temperature. The PCR products were electrophoresed on $1.5 \%$ agarose gel for $90 \mathrm{~min}$ at $85 \mathrm{v}$.

Table 1 Specific primers used for PCR amplifications of genes used for phylotyping

\begin{tabular}{llll}
\hline Gene & Primer Sequence (5'-3') & Band Size (bp) & $\operatorname{Tm}\left({ }^{\circ} \mathrm{C}\right)$ \\
\hline chuA & GAC GAA CCA ACG GTC AGG AT & 279 & 55 \\
& TCG CCA GTA CCA AAG ACA & & \\
yajA & TGA AGT GTC AGG AGA CGC TG & 211 & 55 \\
& ATG GAG AAT GCG TTC CTC AAC & & \\
TSP & GAG TAA TGT CGG GGC ATT CA & 152 & 55 \\
& CGC GCC AAC AAA GTA TTA CG & & \\
\hline
\end{tabular}


Table 2 PCR primer used for detection of Colicin genes

\begin{tabular}{|c|c|c|c|}
\hline Name of Colicin & Primer Sequences ( $5^{\prime}$ to $3^{\prime}$ ) & Band Size (bp) & $\operatorname{Tm}\left({ }^{\circ} \mathrm{C}\right)$ \\
\hline Colicins A, N, S4 & $\begin{array}{l}\text { CGT AGC TAT AAT GAA GCA ATG GCT TCA } \\
\text { ACC TCC AAC AGG AGA GGT CCC CAG Tा }\end{array}$ & 225 & 57 \\
\hline Colicin V & $\begin{array}{l}\text { CAC GCC CTG AAG CAC CAC CA } \\
\text { CCG TाT TCC AAG CGG ACC CC }\end{array}$ & 400 & 68 \\
\hline Colicins $1 a, 1 b$ & $\begin{array}{l}\text { GCA CAA CAG GCC CGT CTG CTC } \\
\text { CAC CTT CCA CAT CCT CTG TCA CC }\end{array}$ & 385 & 68 \\
\hline Colicins E2, E3, E4, E5,E6, E7, E8, E9 & $\begin{array}{l}\text { CGA CAG GCT AAA GCT GTT CAG GT } \\
\text { TGC AGC AGC ATC AAA TGC AGC CT }\end{array}$ & 219 & 60 \\
\hline Colicins $U, Y$ & $\begin{array}{l}\text { GTG AAC GGA CAG AAA CCC GCC } \\
\text { CAA TCT GTC TGA CAG CCT CTC CC }\end{array}$ & 243 & 68 \\
\hline Colicin $5,10, K$ & $\begin{array}{l}\text { AAA GCT GAA CTG GCG AAG GC } \\
\text { CAA CTC ATC ATC CCC TAT GTA AGA AG }\end{array}$ & 803 & 60 \\
\hline Colicin E1 & $\begin{array}{l}\text { ACG GGA GTG GCT CTG GCG G } \\
\text { CTC TाT ACG TCG TTG TTC TGC TTC CTG }\end{array}$ & 389 & 68 \\
\hline
\end{tabular}

The DNA bands were visualized through staining of gels with DNA Fluorescent Loading Dye (Sigma, Germany).

\section{Evaluation of the inhibitory activity of $E$. coli strains}

The sensitivity of the pathogenic E. coli O157:H7 Sakai (EHEC) to the colicins was examined here. The E. coli O157:H7 colonies and the colicin positive strains, which have been identified in the previous steps, were inoculated into Lysogeny Broth (LB; Merck, Germany) and were grown overnight (12 to $16 \mathrm{~h}$ ). The overnight grown strain of $E$. coli $\mathrm{O} 157: \mathrm{H} 7$ was streaked and spread thoroughly on the surface of LB agar plates containing $0.025 \mu \mathrm{g}$ of Mitomycin C (Sigma, USA) and were then allowed to dry. Mitomycin C's role here was to induce the colicins production in the isolated strains. Fresh overnight cultures ( $7 \mu \mathrm{L}$ from each colicinogenic isolates were spotted on the same LB plates that had been in the previous step streaked with E. coli O157:H7. These bacterial test plates were afterwards stored at $37^{\circ} \mathrm{C}$ for 12 to $16 \mathrm{~h}$. Finally, the clearance zones around the spotted $E$. coli isolates were measured [16]. The clear zone indicates no growth of $E$. coli $\mathrm{O} 157: \mathrm{H7}$.

\section{Statistical analysis}

SPSS software (version 17. SPSS Inc., USA) was used for the data analysis. $P$ value was measured using Chi-square and Fisher's exact tests to find any significant relationship. $P$ values less than 0.05 were considered statistically meaningful.

\section{Results}

PCR assay showed that sixty-seven E. coli isolates (45.89\%) from diarrheic samples contained colicin encoding genes. Twenty-five (17.12\%) isolates of them harbored colicin Iab encoding genes and most of these isolates
(15.06\%) contain the virulence genes related to ETEC pathotype. Eighteen (12.32\%) isolates possessed colicin E1 encoding genes and were widely distributed among STEC (9.58\%) pathotype. Fifteen E. coli isolates (10.27\%) were positive for colicin $\mathrm{V}$ encoding genes and were distributed among ETEC (6.16\%) and EIEC (0.68) pathotypes, respectively. Colicin-Iab/ E1/ V were the most prevalent colicin encoding genes and colicin Mix E and colicin 5,10 , k were not detected in any of the diarrheic $E$. coli isolates.

From one hundred and forty-six E. coli isolates of healthy sheep, eleven isolates (7.53\%) contained $s t x_{1}$ and/or $s t x_{2}$ in combination with the eae or/and ehly genes and classified as STEC pathotype. Three isolates $(2.05 \%)$ were positive for $c n f 1$ gene which categorized into NTEC pathotype (Fig. 1). One isolate (0.68\%) was positive for ipaH gene that is an EIEC virulence gene and one hundred twenty $E$. coli isolates from healthy sheep did not have any virulence genes (Fig. 2). The frequency of bacteriocinogeny was $29.45 \%$ among healthy isolates and all types of colicin ending genes were detected in these isolates. The figures of colicin genes are shown in Figs. 3, 4.

Statistical analysis showed that the frequency of colicinogenic isolates in diarrhea associated $E$. coli was significantly higher than $E$. coli isolates from healthy sheep $(p<0.05)$. A specific association between ETEC and colicin V/ colicin Iab encoding genes in diarrheic $E$. coli isolates was observed $(p<0.05)$. In addition, a specific association between ipaH gene and Colicin $\mathrm{V}$ encoding gene was found $(p<0.05)$. Totally, $E$. coli isolates possessing no virulence determinant had (42/43, $97.67 \%)$ and $(8 / 67,11.94 \%)$ frequency of bacterocingeny in healthy and diarrheic isolates, respectively. Altogether, 110 colicin producer strains (37.67\%) were identified of $292 \mathrm{E}$. coli isolates. 


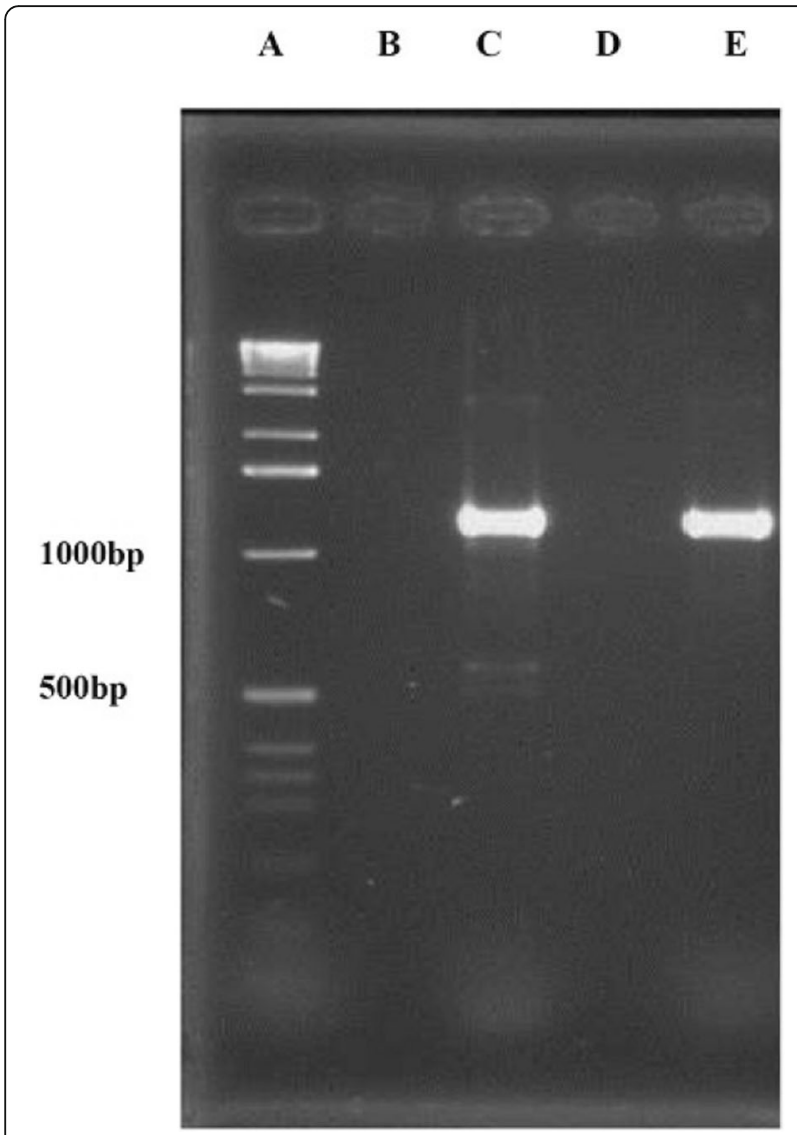

Fig. 1 Molecular detection of NTEC strains. A) DNA Ladder, B) Negative control, C) Positive control (E. coli S5), D) Negative isolate for cnf1 gene (NTEC), and E) Positive isolate for cnf1 gene
Approximately $28 \%$ of the $146 \mathrm{E}$. coli isolates from diarrheic sheep produced inhibitory activity against $E$. coli O157:H7 Sakai (EHEC). Five of these isolates (12.19\%) possess more than one of the mentioned colicin target genes. The largest zone of inhibition belonged to col. E1 producer (12.32\%) and col. V producer (10.27\%) isolates. No zone of inhibition was obtained from diarrheic isolates which were positive for col. Iab and col. yu encoding genes. Thirty two (21.9\%) healthy isolates had the inhibitory effect on E. coli O157:H7 Sakai (EHEC). All types of colicin in healthy isolates had the inhibitory effect on E. coli O157:H7 with the exception of col. Iab. Details of detected colicin encoding genes in relation to the different pathotypes and the inhibitory effect of the colininogenic isolates on E. coli O157:H7 Sakai (EHEC) are shown in Table 3.

Phylogenetic analysis of diarrheic and healthy isolates showed that the highest frequency of colicin encoding genes were found in B1 phylogroup (65.45\%) followed by A (26.36\%), D (7.27\%) and B2 (0.9\%) phylogroups. In B1 phylogroup, colicin E1 (17/45, 37.7\%) and colicin Iab (11/27, 40.74\%) encoding genes were more common in

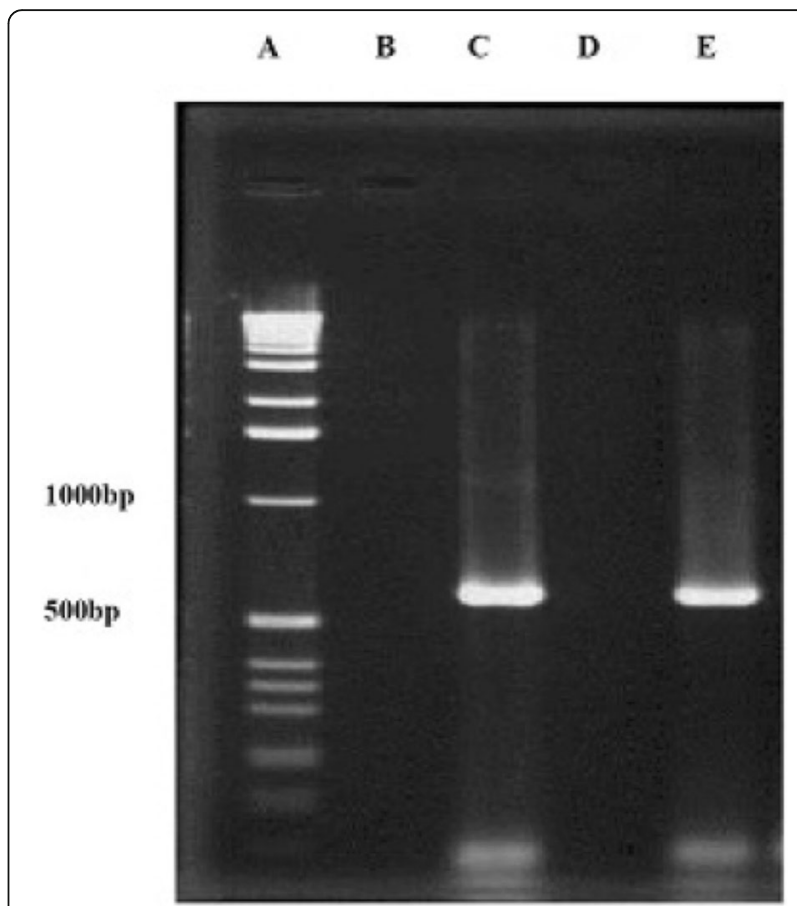

Fig. 2 EIEC strain detection by PCR. A) DNA Ladder, B) Negative control, C) Positive control (E. coli 85b), D) Negative isolate for ipaH gene, and E: Positive isolate for ipaH gene (EIEC)

diarrheic and healthy E. coli isolates, respectively. Producer of colicin $\mathrm{V}$ belonged more frequently to A phylogroup in diarrheic and healthy $E$. coli isolates (22.38, $7.46 \%$, respectively; $p<0.0001)$ when compared to other colicin producer isolates (Table 4).

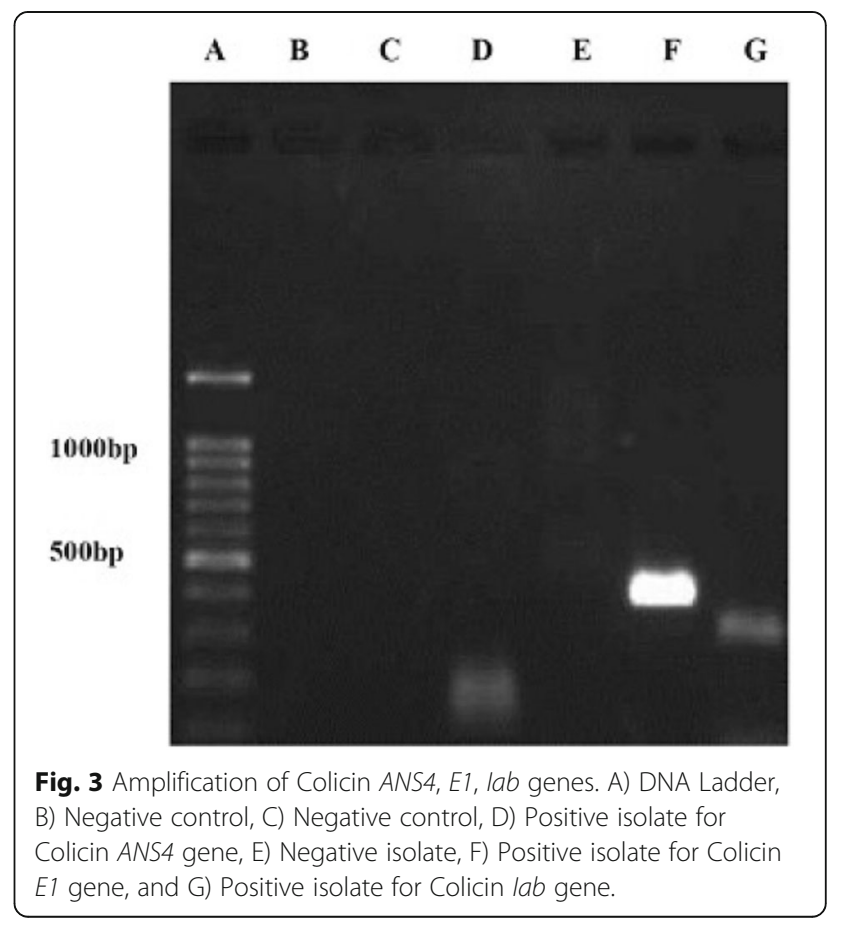




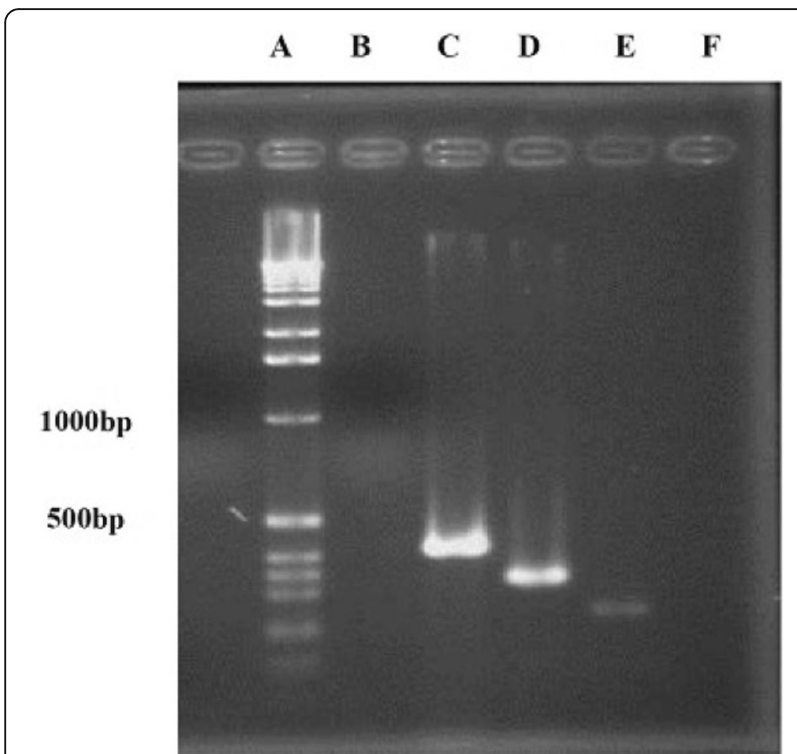

Fig. 4 Detection of Colicin V, YU, and EMix genes. A) DNA Ladder, B) Negative control, C) Positive isolate for Colicin $V$ gene, D) Positive isolate for Colicin YU gene, E) Positive isolate for Colicin EMix gene, and F) Negative control.

\section{Discussion}

In this study, the average prevalence of colicinogenic $E$. coli isolates from sheep was $37.67 \%$. Surprisingly our data lies well within the recently published results from a different source for probiotic E. coli strains, humans [11, 14, 17, 18]. In those studies, Gordon et al., [19] detected 19 types bacteriocin genes when screening $266 \mathrm{E}$. coli strains that had been isolated from human fecal (38\% of these isolates were bacteriocinogenic), and Smaj et al., [20] detected 29 bacteriocin types in 441 human fecal $E$. coli isolates (55\% of which were bacteriocin-encoding isolates). Based on our presented data and the previously published results, sheep could also be considered as a potential source of the probiotic $E$. coli strains.

The results presented here showed that the frequency of bacteriocinogeny in E. coli isolates positively correlates with the number of detected virulence factors. To the best of our knowledge, this is the first time that the correlation between frequency of colicin encoding genes and the number of virulence factors in $E$. coli isolates from sheep have been investigated.

This study also showed that the prevalence of colicin E1 genes among diarrheic isolates was relatively high (10.27\%) in comparison to the other colicin genes. Micenkova et al., [20] reported that colicin E1, which is

Table 3 Relation between Colicin genes and pathotypes of E. coli isolates, and the inhibitory effect of the colininogenic isolates on E. coli O157:H7

\begin{tabular}{|c|c|c|c|c|c|c|c|c|c|}
\hline \multirow[t]{2}{*}{ Colicin genes } & \multirow{2}{*}{\multicolumn{2}{|c|}{$\begin{array}{l}\text { Number of } \\
\text { Isolates }\end{array}$}} & \multicolumn{6}{|l|}{ Pathotypes } & \multirow{2}{*}{$\begin{array}{l}\text { Inhibition } \\
\text { of E. coli } \\
\text { O157:H7 }\end{array}$} \\
\hline & & & ETEC & aEPEC & STEC & NTEC & EIEC & Without Vir Genes & \\
\hline \multirow[t]{2}{*}{ Colicin lab } & $D$ & 25 & 22 & 0 & 0 & 0 & 0 & 3 & - \\
\hline & $H$ & 11 & 0 & 0 & 0 & 0 & 0 & 11 & - \\
\hline \multirow[t]{2}{*}{ Colicin E1 } & $D$ & 18 & 1 & 1 & 14 & 2 & 0 & 0 & + \\
\hline & $H$ & 5 & 0 & 0 & 0 & 0 & 0 & 5 & + \\
\hline \multirow[t]{2}{*}{ Colicin V } & $D$ & 15 & 9 & 0 & 0 & 0 & 1 & 5 & + \\
\hline & $H$ & 5 & 0 & 0 & 0 & 0 & 1 & 4 & + \\
\hline \multirow[t]{2}{*}{ Colicin $5,10, \mathrm{~K}$} & $D$ & 3 & 0 & 2 & 1 & 0 & 0 & 0 & + \\
\hline & $H$ & 5 & 0 & 0 & 0 & 0 & 0 & 5 & + \\
\hline \multirow[t]{2}{*}{ Colicin YU } & $D$ & 1 & 0 & 0 & 1 & 0 & 0 & 0 & - \\
\hline & $H$ & 6 & 0 & 0 & 0 & 0 & 0 & 6 & + \\
\hline \multirow[t]{2}{*}{ Colicin EMix } & $D$ & 0 & 0 & 0 & 0 & 0 & 0 & 0 & - \\
\hline & $H$ & 3 & 0 & 0 & 0 & 0 & 0 & 3 & + \\
\hline \multirow[t]{2}{*}{ Colicin ANS4 } & $D$ & 0 & 0 & 0 & 0 & 0 & 0 & 0 & - \\
\hline & $H$ & 2 & 0 & 0 & 0 & 0 & 0 & 2 & + \\
\hline \multirow[t]{2}{*}{ Multiple Colicin genes } & $D$ & 5 & 3 & 1 & 1 & 0 & 0 & 0 & + \\
\hline & $H$ & 6 & 0 & 0 & 0 & 0 & 0 & 6 & + \\
\hline \multirow[t]{2}{*}{ Total } & $D$ & 67 & $35(52.23)$ & $4(5.97)$ & $17(25.37)$ & $2(2.98)$ & $1(1.49)$ & $8(11.9)$ & \\
\hline & $H$ & 43 & 0 & 0 & 0 & 0 & $1(2.32)$ & $42(97.6)$ & \\
\hline
\end{tabular}


Table 4 Detected Colicin genes in relation to phylogenetic groups/subgroups in E. coli isolated form diarrheic and healthy sheep

\begin{tabular}{|c|c|c|c|c|c|c|c|c|c|}
\hline \multirow{3}{*}{$\begin{array}{l}\text { Target gene } \\
\text { Colicin lab }\end{array}$} & \multirow{2}{*}{\multicolumn{2}{|c|}{$\begin{array}{l}\text { Phylogenetic group } \\
\text { Phylogenetic subgroup }\end{array}$}} & \multicolumn{2}{|l|}{ A } & \multirow{3}{*}{$\begin{array}{l}\text { B1 } \\
\text { B1 } \\
20\end{array}$} & \multicolumn{2}{|l|}{ B2 } & \multicolumn{2}{|l|}{ D } \\
\hline & & & \multirow{2}{*}{$\begin{array}{l}\mathrm{A} 0 \\
-\end{array}$} & \multirow{2}{*}{$\begin{array}{l}\mathrm{A} 1 \\
-\end{array}$} & & \multirow{2}{*}{$\begin{array}{l}\mathrm{B} 2-2 \\
-\end{array}$} & \multirow{2}{*}{$\begin{array}{l}\mathrm{B} 2-3 \\
-\end{array}$} & \multirow{2}{*}{$\frac{D 1}{5}$} & \multirow{2}{*}{$\frac{\mathrm{D} 2}{-}$} \\
\hline & $\mathrm{D}$ & 25 & & & & & & & \\
\hline & $\mathrm{H}$ & 11 & - & - & 11 & - & - & - & - \\
\hline \multirow[t]{2}{*}{ Colicin E1 } & $\mathrm{D}$ & 18 & 1 & - & 17 & - & - & - & - \\
\hline & $\mathrm{H}$ & 5 & - & - & 2 & - & - & 3 & - \\
\hline \multirow[t]{2}{*}{ Colicin V } & $\mathrm{D}$ & 15 & 10 & 5 & - & - & - & - & - \\
\hline & $\mathrm{H}$ & 5 & 4 & 1 & - & - & - & - & - \\
\hline \multirow[t]{2}{*}{ Colicin 5, 10, K } & $\mathrm{D}$ & 3 & - & - & 3 & - & - & - & - \\
\hline & $\mathrm{H}$ & 5 & 1 & 4 & - & - & - & - & - \\
\hline \multirow[t]{2}{*}{ Colicin $Y, U$} & $\mathrm{D}$ & 1 & - & - & - & 1 & - & - & - \\
\hline & $\mathrm{H}$ & 6 & - & 1 & 5 & - & - & - & - \\
\hline \multirow[t]{2}{*}{ Colicin EMix } & $\mathrm{D}$ & 0 & - & - & - & - & - & - & - \\
\hline & $\mathrm{H}$ & 3 & - & - & 3 & - & - & - & - \\
\hline \multirow[t]{2}{*}{ Colicin A, N, S4 } & $\mathrm{D}$ & 0 & - & - & - & - & - & - & - \\
\hline & $\mathrm{H}$ & 2 & - & 2 & - & - & - & - & - \\
\hline \multirow[t]{2}{*}{ Multiple Colicin genes } & $\mathrm{D}$ & 5 & - & - & 5 & - & - & - & - \\
\hline & $\mathrm{H}$ & 6 & - & - & 6 & - & - & - & - \\
\hline \multirow[t]{2}{*}{ Total } & $\mathrm{D}$ & 67 & 11 & 5 & 45 & 1 & - & 5 & - \\
\hline & $\mathrm{H}$ & 43 & 5 & 8 & 27 & - & - & 3 & - \\
\hline
\end{tabular}

a pore-forming bacteriocin, had a high prevalence in fecal and also in human UPEC isolates.

The prevalence of colicing Iab genes of $E$. coli isolates from diarrheic and healthy sheep (17.12 and 25.56\%, respectively) were significantly higher than other colicin genes. This is in accordance with the study of Micenková., et al., [11, 14]. Another study showed that colicin $\mathrm{Ia} / \mathrm{Ib}$ was one of the most frequent colicin types among ETEC isolates and also $38.2 \%$ of Shigella sonnei isolates produced colicin Ia/Ib [17]. In the present study, $15.06 \%$ of 292 of fecal isolates were positive for colicin Ia/Ib encoding gene and also categorized in ETEC pathotype.

The prevalence of colicin $\mathrm{V}$ encoding gene in healthy and diarrheic isolates was equal and there was a specific association between ipaH virulence gene and this type of colicin. This finding is in accordance with the previous studies, which showed that colicin $\mathrm{V}$ encoding plasmids are more commonly carried by the virulent E. coli isolates [7].

Furthermore, colicin $\mathrm{Y}$ is related to the colicin $\mathrm{U}$ that was isolated around 20 years ago in Europe from Shigella boydii. Colicin $\mathrm{Y}$ is rarely detected colicin type in Europe, but high frequency of colicin $\mathrm{Y}$ producers were detected in E. coli isolated in Amazonia [11]. In our study the prevalence of colicin $\mathrm{Y} / \mathrm{U}$ genes was relatively low in both healthy and diarrheic isolates. Moreover, productions of nucelase colicins E2-E9 are also very rare in $E$. coli isolates. [18, 19, 21]. In this study, none of the diarrheic isolates were positive for colicin E2-E9 encoding genes.

Association of E. coli phylogroups and bacteriocin types has been tested in several previous publications, which produced different results. Gordon and O'Brien [19] tested a set of 266 fecal E. coli isolates and failed to find remarkable differences in the prevalence of bacteriocin determinants among the phylogroups. They reported phylogroup $\mathrm{A}$ and $\mathrm{B} 1$ tended to encode more colicin types, while in phylogroup A, genes encoding E1, Ia and $\mathrm{V}$, were most common [21]. In this study, phylogenetic analysis of diarrheic and healthy isolates showed that the highest frequency of colicin encoding genes were found in B1 phylogroup (65.45\%) followed by A (26.36\%), D (7.27\%) and B2 (0.9\%) phylogroups. In phylogroup B1, colicin E1 and colicin Iab encoding genes were more common.

Setia et al., [16] showed that the colicin produced by $26.8 \%$ of $E$. coli isolates without known toxin genes recovered from healthy cattle were able to inhibit the growth of pathogenic E. coli K88. The present study showed that fifty $E$. coli isolates $(50 / 292,17.12 \%)$ from diarrheic and healthy sheep were able to produce different types of colicin, while they didn't have any virulence factors. Thirty six isolates of them (12.32\%) were able to inhibit the growth of E. coli O157:H7 Sakai (EHEC) in vitro. So, colicin produced by these isolates may potentially provide an effective strategy to reduce $E$. coli 
O157:H7 in food animals. In the recent study, all types of colicin were able to inhibit E. coli $\mathrm{O} 157: \mathrm{H} 7$ except for colicin Ia/Ib which is in agreement with the previous studies [22, 23]. Bradley et al., [24] considered that O157 isolates were most likely resistant due to masking of the colicin $\mathrm{Ia} / \mathrm{Ib}$ receptor by $\mathrm{O}$-antigen side-chains of LPS. Another explanation for this resistance is that some E. coli O157:H7 isolates are colicinogenic and produce specific concomitant immunity proteins [23], they can be resistant to certain colicins or even a broad classes of colicins. [25]. On the other hand, this possibility should be considered that O157:H7 Sakai (EHEC) of human could have resistance against the colicins of strains isolated from sheep. Therefore, simultaneous administration of a mixture of several classes of colicins should be considered as a treatment to reduce E. coli O157:H7 (and other EHEC) in the gastrointestinal tract of food animals. [23]

In this study, all types of colicin encoding genes in $E$. coli isolated from healthy sheep were detected. Whereas, E. coli isolates from diarrheic sheep didn't harbored colicin Mix E/ANS4 encoding genes. Previous studies found colicinogenic isolates from all sources, but the greatest types of colicin were from cats and sheep $[9,26]$. Tahamtan et al., [27] reported that Ia/Ib and ANS4 colicin encoding genes had the highest frequency among E.coli strains isolates from healthy and diarrheic cattle in Shiraz, Iran. It can be concluded that many factors may influence the types of detected colicin genes including species, illness, diet and geographical conditions [28].

\section{Conclusion}

The results and data presented in our report showed that the healthy sheep could be considered as a source of colicinogenic E. coli strains. These E. coli strains that do not harbor any virulent factors but are carrying the colicin genes are a potentially valuable source for anti-O175: $\mathrm{H7}$ bacterial isolates. Further work is granted to study the in vivo inhibitory effects of these colicinogenic isolates of $E$. coli on the biocontrol of pathogenic O175:H7. On the other hand, it can be concluded that there is a correlation between presence of colicin genes and virulence genes in E. coli isolates which could be determined in the future studies.

\footnotetext{
Abbreviation

a EPEC: atypical Entropathogenic E. coli; chuA: E. coli haem-utilization gene; cnf: cytotoxic necrotizing factor; eae: attaching and effacing gene of E. coli; EHEC: Enterohemorrhagic E. coli; EIEC: Entroinvasive E. coli;

ETEC: Entrotoxigenic E. coli; HUS: Hemolytic Uremic Syndrome; ipaH: invasion plasmid antigen; LT: heat labile toxin.; NTEC: Necrotoxic E. coli; PCR: Polymerase Chain Reaction; SPSS: Statistical Package for the Social Sciences; ST: heat-stable enterotoxin; STEC: Shiga Toxin producing E. coli; Stx: Shiga toxin; TspE4.C2: an anonymous DNA fragment in E. coli; yjaA: E. coli K12 gene
}

\section{Acknowledgments}

The authors would like to thank Dr. Eric Oswald (Ecole Nationale Vétérinaire Toulouse, France) and Pasture Institute of Iran for providing the reference strains.

\section{Funding}

This work was financially supported by a Grant from the Iran National Science Foundation grant number 93027693.

\section{Availability of data and materials}

All data generated or analyzed during this study are available from the corresponding author on reasonable request.

\section{Authors' contributions}

NA and RG designed the study, NA performed the experiments, NA and RG analyzed the data and NA and RG wrote and drafted the manuscript. NA and RG read and approved the final manuscript.

\section{Ethics approval and consent to participate}

All investigations were conducted in accordance with the Guiding Principles for the Care and Use of Animals was approved by the Ethics Committee of Faculty of Veterinary Medicine, Shahid Bahonar University of Kerman, Iran.

Consent for publication

Not applicable.

\section{Competing interests}

The authors declare that they have no competing interests.

\section{Publisher's Note}

Springer Nature remains neutral with regard to jurisdictional claims in published maps and institutional affiliations.

\section{Author details}

${ }^{1}$ Department of Pathobiology, Faculty of Veterinary Medicine, Shahid Bahonar University of Kerman, Kerman, Iran. ${ }^{2}$ Molecular Microbiology Research Group, Faculty of Veterinary Medicine, Shahid Bahonar University of Kerman, Kerman, Iran.

Received: 13 June 2018 Accepted: 28 December 2018

Published online: 07 January 2019

\section{References}

1. Abdissa R, Haile W, Fite AT, Beyi AF, Agga GE, Edao BM, et al. Prevalence of Escherichia coli O157: H7 in beef cattle at slaughter and beef carcasses at retail shops in Ethiopia. BMC Infect Dis. 2017;17:277.

2. Ferens WA, Hovde CJ. Escherichia coli O157:H7: animal reservoir and sources of human infection. Foodborne Pathog Dis. 2011:8:465-87.

3. Rahal EA, Kazzi N, Nassar FJ, Matar GM. Escherichia coli 0157:H7_clinical aspects and novel treatment approaches. Front Cell Infect Microbiol. 2012; 2:138.

4. Elder RO, Keen JE, Siragusa GR, Barkocy-Gallagher GA, Koohmaraie M, Laegreid WW. Correlation of enterohemorrhagic Escherichia coli 0157 prevalence in feces, hides, and carcasses of beef cattle during processing. Proc Natl Acad Sci. 2000;97:2999-3003.

5. Schamberger GP, Diez-Gonzalez F. Assessment of resistance to Colicinogenic Escherichia coli by E. coli O157:H7 strains. J Appl Microbiol. 2005:98:245-52.

6. Schamberger GP, Diez-Gonzalez F. Characterization of Colicinogenic Escherichia coli strains inhibitory to enterohemorrhagic Escherichia coli. J Food Prot. 2004;67:486-92

7. Jeziorowski A, Gordon DM. Evolution of microcin V and Colicin la plasmids in Escherichia coli. J Bacteriol. 2007:189:7045-52.

8. Inglis RF, Bayramoglu B, Gillor O, Ackermann M. The role of bacteriocins as selfish genetic elements. Biol Lett. 2013;9 20121173-20121173.

9. Diez-Gonzalez F. Applications of bacteriocins in livestock. Curr Issues Intest Microbiol. 2007:8:15-23.

10. Zhao T, Doyle MP, Harmon BG, Brown CA, Mueller POE, Parks AH. Reduction of carriage of enterohemorrhagic Escherichia coli 0157:H7 in cattle by inoculation with probiotic bacteria. J Clin Microbiol. 1998;36:641-7. 
11. Micenková L, Bosák J, Štaudová B, Kohoutová D, Čejková D, Woznicová V, et al. Microcin determinants are associated with B2 phylogroup of human fecal Escherichia coli isolates. Microbiology. 2016;5:490-8.

12. Chandran A, Mazumder A. Prevalence of diarrhea-associated virulence genes and genetic diversity in Escherichia coli isolates from fecal material of various animal hosts. Appl Environ Microbiol. 2013;79:7371-80.

13. Clermont O, Bonacorsi S, Bingen E. Rapid and simple determination of the Escherichia coli phylogenetic group. Appl Environ Microbiol. 2000;66:4555-8.

14. Micenková L, Bosák J, Vrba M, Ševčíková A, Šmajs D. Human extraintestinal pathogenic Escherichia coli strains differ in prevalence of virulence factors, phylogroups, and bacteriocin determinants. BMC Microbiol. 2016;16.

15. Ghanbarpour R, Askari N, Ghorbanpour M, Tahamtan Y, Mashayekhi K, Afsharipour N, et al. Genotypic analysis of virulence genes and antimicrobia profile of diarrheagenic Escherichia coli isolated from diseased lambs in Iran. Trop Anim Health Prod. 2017;49:591-7.

16. Setia A, Bhandari SK, House JD, Nyachoti CM, Krause DO. Development and in vitro evaluation of an Escherichia coli probiotic able to inhibit the growth of pathogenic Escherichia coli K88. J Anim Sci. 2009;87:2005-12.

17. Micenková L, Štaudová B, Bosák J, Mikalová L, Littnerová S, Vrba M, et al. Bacteriocin-encoding genes and EXPEC virulence determinants are associated in human fecal Escherichia coli strains. BMC Microbiol. 2014; 14:109.

18. Šmajs D, Čejková D, Micenková L, Lima-Bittencourt Cl, Chartone-Souza E, Šmarda J, et al. Human Escherichia coli strains of different geographical and time source: Bacteriocin types and their gene sequences are populationspecific. Environ Microbiol Rep. 2012:4:459-66.

19. Gordon DM, O'Brien CL. Bacteriocin diversity and the frequency of multiple bacteriocin production in Escherichia coli. Microbiology. 2006;152:3239-44.

20. ŠŠmajs D, Micenková L, ك̌Šmarda J, Vrba M, Ševčíková A, Vališová Z, et al. Bacteriocin synthesis in uropathogenic and commensal Escherichia coli: Colicin E1 is a potential virulence factor. BMC Microbiol. 2010;10:288.

21. Kohoutova D, Smajs D, Moravkova P, Cyrany J, Moravkova M, Forstlova M, et al. Escherichia coli strains of phylogenetic group B2 and D and bacteriocin production are associated with advanced colorectal neoplasia. BMC Infect Dis. 2014:14:733.

22. Toshima H, Yoshimura A, Arikawa K, Hidaka A, Ogasawara J, Hase A, et al. Enhancement of Shiga toxin production in enterohemorrhagic Escherichia coli serotype O157:H7 by DNase Colicins. Appl Environ Microbiol. 2007;73: 7582-8

23. Callaway TR, Stahl CH, Edrington TS, Genovese KJ, Lincoln LM, Anderson RC, et al. Colicin concentrations inhibit growth of Escherichia coli 0157:H7 in vitro. J Food Prot. 2004;67:2603-7.

24. Bradley DE, Howard SP, Lior H. Colicinogeny of O157:H7 enterohemorrhagic Escherichia coli and the shielding of Colicin and phage receptors by their O-antigenic side chains. Can J Microbiol. 1991;37:97-104.

25. Alonso G. How bacteria protect themselves against channel-forming Colicins. Int Microbiol. 2000;3:81-8.

26. Garrett WS, Gallini CA, Yatsunenko T, Michaud M, Dubois A, Delaney ML, et al. Enterobacteriaceae act in concert with the gut microbiota to induce spontaneous and maternally transmitted colitis. Cell Host Microbe. 2010;8: 292-300.

27. Tahamtan Y, Shirazi Z, Pourbakhsh A, Kargar A. Detection of Colicin genes by PCR in Escherichia coli isolated from cattle in shiraz-Iran. Archives of Raz Institute. 2012:63-7.

28. Murinda SE, Liu SM, Roberts RF, Wilson RA. Colicinogeny among Escherichia coli serotypes, including $\mathrm{O} 157: \mathrm{H7}$, representing four closely related diarrheagenic clones. J Food Prot. 1998:61:1431-8.

Ready to submit your research? Choose BMC and benefit from:

- fast, convenient online submission

- thorough peer review by experienced researchers in your field

- rapid publication on acceptance

- support for research data, including large and complex data types

- gold Open Access which fosters wider collaboration and increased citations

- maximum visibility for your research: over $100 \mathrm{M}$ website views per year

At $\mathrm{BMC}$, research is always in progress.

Learn more biomedcentral.com/submissions 